\title{
Participatory Action Research with young people in museums
}

Vasiliki Tzibazi

Department of Teacher Development, University of Winchester, Winchester, UK

Museums and galleries, having received increased funding to engage in their programmes young people who have traditionally been excluded by museums, are under pressure to demonstrate the impact of the programmes they offer. This paper drawing on a three-year Participatory Action Research (PAR) programme explores the hidden tensions that underpin the notion of young people's inclusion in museums. First it considers the reasons for adopting the PAR approach and presents its key principles. Then it reflects on the research processes and discusses the findings to provide an insight into the quality of the experiences offered to young people. It argues that there is an implicit deficiency perception of youth and suggests the use of PAR as a response both to the need for a deeper notion of inclusion and for research that values young people's voices.

Keywords: young people; museums; participation; inclusion; Participatory Action Research

\section{Introduction}

Since the introduction of the UK's New Labour governmental agenda for social inclusion, museums have sought to act as agents for social change and to engage in their programmes young people (aged 13 19) who have traditionally been excluded by the museums. Although there is an ongoing discourse about the way museums and galleries exclude and include individuals and social groups in their cultural practices (Coffee 2008; Leahy 2007; Newman and McLean 2004; Sandell 2002; Tlili 2008; Tlili, Gerwirtz, and Cribb 2007), there is a lack of in-depth qualitative research in the area of young people's engagement in museum programmes. Research has mainly focused on exploring the young people's attitudes towards art museums and galleries to bridge the gap between the institutions' educational provision and the target group (Mason and McCarthy 2006; Xanthoudaki 1998). The need for emancipatory pedagogies in programmes for young people has been clearly articulated in pilot work in art galleries in which new channels and educational practices are sought to reach young people (Briggs 2007; Herne and McLaren 2001; Sayers 2011). 
This paper explores the notions of youth and inclusion that underpin museum practices as illustrated in the current literature and research about the role of museums and galleries as agents for social change. The discussion is placed within the context of a three-year Participatory Action Research (hereafter PAR) museum programme in the UK to claim that there might be an underlying perception of youth deficiency reinforced by the demand for museums to measure social impact.

The programme, ${ }^{1}$ funded by various bodies including Arts Organizations and the Department of Culture, Media and Sport, took place in a local authority museum for the threeyear period, 2005 2008. It aimed to engage a group of 15 white teenagers aged between 13 and 14 years in the regeneration of their local museum and library, both of which are located in the same building. The young people who participated in the project were selected from a secondary school that is located in a deprived area of the city and for whom attainment is below that of the national average. The group originally comprised seven females and eight males, but as the programme progressed six females and one male withdrew from the programme.

The focus for the discussion that follows is based on my experience as a project coordinator and evaluator of the programme. Overall, supervision of the programme was undertaken by the Learning Officer attached to the museum, with further support from artists and freelance workers as required, particularly within the second and third years. Staff from the local museum were also involved on an occasional basis to support the programme's needs. In order to gain an understanding of the participants' response to the programme, group discussions and individual reflec- tions were sought. These were audio-recorded either by the peer group or the project coordinator. At the final stage of the project the young people and the museum staff were also interviewed by the evaluator/project coordinator. Voice recorders were also given to the young people to use them as a diary where thoughts about their experiences were kept.

Based on the principles that underpin the PAR approach and typical extracts that illustrate the views of the young people and staff, I explore the processes of participation in a PAR project to claim that a deeper notion of participation is required so that inclusion of young people in museum projects is not a shift in rhetoric but a meaningful experience for all involved. This paper aims to propose PAR as an emancipatory model for research and pedagogy (in the sense that is driven by the participants themselves) for young people's inclusion in museums. 


\section{Inclusion, museums and young people}

Over the past decade there has been a growing interest in the UK on extending young people's access to and participation in culture. This agenda stems from the notions of social inclusion and cultural democracy that were at the heart of the New Labour government vision of building a culture of participation for children and young people within services and policy making. Although currently there is a new Coalition government that continues to introduce drastic changes to museum funding, it is worth re-visiting the initiatives that laid the foundations about the role that museums can play as agents of inclusion for young people. Museums still need to develop meaningful frameworks to analyse more deeply the practices of the social work they have been offering (Silverman 2010) and become clearer about the way young people's participation in museum programmes will be developed and sustained (Rosso 2010).

In the UK, New Labour government policy identified inclusion as what can be done primarily via multi-agency working to tackle social exclusion (SEU 2004). The responsibility was devolved to institutions that were expected to collaborate to give a sense of belonging to those who were seen to be excluded from the community. Museums were seen as institutions that could play an important role in empowering marginalised groups within the communities 'to determine their place in the world' and 'achieve their own potential' (DCMS 2000, 8). It was believed that the involvement in culture and learning improves educational attainment; enhances people's abilities, skills and confidence to engage with society; and as a result combats exclusion.

Young people (aged 13-19) were amongst the targeted socially disadvantaged and marginalised groups that museums needed to reach and include in their audiences. They were identified by funding bodies as 'an under-represented' and 'hard to reach audience' and therefore as a target group for their grants (i.e. the Heritage Lottery Fund, regional developmental agencies, Arts Council England).

Over the years 2004-2006, $£ 7,000,000$ was invested in museum education programmes to enrich the learning of school-age children and young people across country. Building on this scheme a $£ 9,400,000$ investment in museum and galleries education took place from 2006 to 2008 to strengthen 'the ability of museums and galleries to support children and young people's education' (DCMS 2005a). This interest in the sector was further encouraged by the launch of the DFES (2006a) 'Learning Outside the Classroom Manifesto', the 'Aiming high for young 
people' (DFES 2007) ten-year strategy to transform leisure-time opportunities for young people and the 'Youth Matters' initiative that was published as a Green paper (DFES 2005). The later consultation with over 19,000 young people, set out the vision of empowering young people giving them more access to culture, opportunities to contribute to their local community and influence in the shaping of services and facilities that are available to them (DFES 2006b). Whilst these initiatives instigated development of new programmes ${ }^{2}$ and a participatory shift in museum practice they were not firmly grounded in a theoretical framework.

For a decade the museum sector was preoccupied with the production of guidelines to explore why young people had been 'under-represented' in museums and evaluations of projects that provide evidence of the impact museums could have on changing young people's lives (see BOP 2006; DCMS 2005b; Discovery 2011; Harris and Dudley 2011; Hawthorne and Pontin 2001; Wavell et al. 2002). A common thread that underpins these reports is the aim of museum programmes to promote social cohesion by raising young people's self-esteem and confidence to play an active role within the community. These initial, early reports (Harland and Kinder 1999; Ings 2001; Rider and Illingworth 1997), supported with a strand of research on young people's attitudes and low visitation to museums and galleries (Mason and McCarthy 2006; Xanthoudaki 1998), focus on the characteristics of young people from a sociological and psychological perspective that could account for a reluctance to visit museums. They explore teenagers' preferences, behaviour and preconceptions that discourage them from museum/gallery visiting. In so doing they identify lack of motivation, parental influence, physical barriers including cost, travel and lack of time and views of art galleries as uninviting spaces as few of the factors that set barriers to young people's access to culture (Barlett and Kelly 2009; Harland and Kinder 1999). Amongst the issues and challenges that museums need to take into account when involving young people in educational projects are the lack of commitment that young people demonstrate for the projects and the low standards of their finished work (Harland and Kinder 1999; Ings 2001; Rider and Illingworth 1997). Thus young people are identified as indifferent to what museums and galleries have to offer. Institutions, however, are urged to stimulate demand for cultural engagement by understanding better what motivates young people to engage in culture (DCMS 2007,6) and making 'it easier for them [the young people] to cross that invisible line' (Harland and Kinder 1999, 11). Even if these views do not portray explicitly deficit perceptions of youth, they certainly pose questions about the quality of a participatory and inclusive culture that museums are invited to develop. 
Hooper-Greenhill identifies the changes that museums were undergoing during the last quarter of the twentieth century under the rubric of two paradigmatic pedagogic formations: 'pedagogy as transmission' and 'pedagogy as culture' (Hooper-Greenhill 2000, 125, 2007). The first, focusing on the transmission of fixed meanings, views visitors who are in need of instruction and who are intended to act as receivers of knowledge, as 'deficient'. The second reconceptualises museum visitors as differentiated groups who are actively engaged in processes of interpreta- tion. It is important for museums, if they want to be viable community institutions, not just to present their cultural offerings to their visitors or potential visitors but to create processes where visitors can be participants and act as co-creators of knowledge and museum experiences. For Maxine Greene, it is the teachers' active engagement and their willingness to take risks, to pose questions and to release imagination that allows both those who are teaching and learning to 'reach beyond, $[\ldots]$ not toward the predictable, but toward the possible' (Greene 2001, 163). If museums are placed in the role of the teacher then there is a need for difficult questions to be asked. How open are museums prepared to be to their communities and what are museums hoping or intending to share? If the aim of the recent initiatives is to improve young people's lives and include in museum practices a 'hard to reach audience', then it is worth researching the quality of the experiences offered to young people. Are young people co-creators of the produced experiences? Why is it important for the museums that young people accept and embrace the experiences that museums offer? To what extent are museums willing to take risks and offer experiences that unleash the full potential of the participants and their imaginations?

Young people's engagement in the design and delivery of programmes became a requirement in the Heritage Lottery Fund Young Roots programme (HLF 2010, 2007). Art galleries have taken the lead in the exploration of new channels to reach young people (Briggs 2007) and the development of programmes that intend to challenge canonical views of art and productions of knowledge within the gallery space $^{3}$ (Herne and McLaren 2001; Sayers 2011). Art galleries' experimental approaches to art interpretation highlight the need for the development of emancipatory pedagogies in museum/gallery education that acknowledge young people's expertise in the learning process (Sayers 2011). In the National Museum Directors' Conference report 'Learning to Live', it is asserted that museums, schools and government need to take further action to enable young people to have equal status with adults within museums and embrace a more holistic approach to learning (Bellamy and Oppenheim 2009). 
The call for embracement of emancipatory pedagogies should not be seen in isolation from the need for the design of inclusive research methodologies that value young people's voices, acknowledge their expertise in the enquiry and locate them as co-researchers (Potter 2006). Museums have been criticised that by being accountable to the funding bodies and the programmes' stakeholders they have become habituated to articulating their offer in terms of the attributes required by instrumental governmental policies (Scott 2002; Selwood Associates 2010). Research is needed that moves beyond the production of evidence for advocacy purposes (Belfiore and Bennett 2010; DCMS 2008; Selwood Associates 2010; Shared Intelligence 2007) and the use of generic evaluation frameworks (MLA 2008). As pointed out by Pontin (2009) if museums wish to obtain a critical understanding into young peoples' experiences and museum practice, researchers need to offer a transparent perspective into the research design, its epistemological stance and procedures for data generation and analysis.

\section{Principles of PAR}

PAR, rooted in social justice movements such as feminism, antiracism and neo- Marxism (see Cahill 2007a; Fals Borda 2006), has long been associated with projects that aim to examine an issue from the perspectives of the community members that are affected by the issue and to place a critical gaze on institutions and their practices (Kemmis and McTaggart 2005; McIntyre 2000). While PAR can be applied in diverse contexts and comes in various forms, there are some core principles that underpin it as an approach it challenges the notion that legitimate knowledge lies with the experts, engages people actively in the generation of knowledge that informs action and transforms "actual practices ... in "the here and now", (Kemmis and McTaggart 2005, 564).

The PAR approach views control of knowledge by those who are the experts as a means for reproducing unequal power relations (Gaveta and Cornwall 2006; Reason and Bradbury 2006). It values differing forms of knowing that arise in the process of living and views the production of knowledge in partnership with the people involved. PAR as an approach seeks to re-examine what and who has been framed as a problem and to involve the participants in the formulation of the enquiry (McIntyre 2008; Pain and Francis 2003). This key feature constitutes PAR not a 'method' but a 'radical epistemological challenge ... . [that] stands on the grounds that persons who have historically been marginalised or silenced carry substantial 
knowledge about the architecture of injustice' (Fine 2008, 215 and 223). PAR is a process in which the participants individually and collectively examine their 'knowledge (understandings, skills, and values)' and 'ways they interpret themselves and their action' first to reflect critically on and then to release themselves from the 'social structures that limit their selfdevelopment and self-determination' (Kemmis and McTaggart 2005, 567). Through PAR people recognise the prevailing norms and the boundaries, they question what has been imposed as a norm and envision alternatives (Krimerman 2001). Emancipatory participation and reflection lie at the heart of this process.

Paulo Freire's theory of 'conscientisation' has contributed significantly to the conceptualisation of PAR as an empowering process. The term 'conscientisation' refers to oppressed communities becoming conscious of the values they have internalised in order to engage more dynamically with structures of power and so transform their reality (Freire [1970]1993). Freire identified a 'banking concept of education' in which theory and practice perpetuate structures of inequality by treating a learner as 'an empty "mind" passively open to the reception of deposits from the world outside' (Freire [1970]1993, 56). In critical learning conditions 'to know how to teach is to create possibilities for the construction and production of knowledge' (Freire 1998, 49). Freire argued that only when learners critically consider reality through dialogic and problem-posing pedagogy, can they view themselves not as passive entities that merely are in the world but as active conscious beings with the world. They become 'beings for themselves' who want to live in a just society and perceive reality as a process in constant transformation (Freire [1970]1993, 55). They see that neither their own attitudes nor the conditions in the macro-level have to remain as they are and that they can engage in actions to change these realities.

Praxis and dialogue are interrelated to this process of critical reflection and realisation. To create the conditions in which authentic praxis and reflection can occur, learner and teacher need to re-create knowledge as equal partners. Through dialogue that presupposes equality amongst the participants, trust, mutual respect and love, the participants can engage in 'an act of creation' (Freire [1970]1993, 70) and so communicate their reflections in the quest for a transformed world. This dialogic relationship is also a necessity in the PAR process; the participants' lived experience is the starting point for the research process in which they act as equals operating 'out of their initial frames of reference at a level where frames can be changed and new frames generated' (Elden and Levin 1991, 134). Interaction at this level is more 
demanding than consultation or mere exchange of information. It is a 'cogenerative dialogue' and a prerequisite for participation in the enquiry as co- creators (Elden and Levin 1991, 134).

While within PAR participants ideally reconstitute themselves as active and reflective agents, the degree and nature of participation within the research might vary significantly (Kindon, Pain and Kesby 2010). Researchers need to consider the participants' needs, the purpose of their involvement in the project and actively engage the participants in all stages of the enquiry. Critiques of participatory research suggest that there is an inherent danger of tokenism when participation is used as a methodological technique rather than a commitment for change (Cahill 2007a; Cooke and Kothari 2001; Pain, Kesby, and Kindon 2010; Pain and Francis 2003).

\section{Implementing PAR and findings}

In this research, PAR was approached both as a pedagogy for the young people's engagement in the local museum's regeneration and a framework for research with the young people that would offer a qualitative perspective on the emerged experiences and processes. Engagement in PAR was seen as a combining investiga- tion of the young people's exclusion from the museum's practices and the regeneration of the museum as a community institution. Young people's lived experiences and knowledge were considered as the starting point for a research process in which all partners involved in the project would be equal partners in a dialectic relationship. The participants through 'a cyclical process of exploration, knowledge production and action' (McIntyre 2008, 1) would investigate reality in order to change it or as Kemmis and McTaggart state 'change reality in order to investigate it' $(2005,567)$.

Initially, open-ended questionnaires designed by young people were completed by the whole year-9 group who were invited to participate in the research. The responses indicated that the group visited museums and galleries only as part of the school's compulsory fieldtrips. Museums were seen as places that 'are of no interest, 'old, dead and boring' focused on the preservation of the past. These findings were not entirely unexpected as similar perceptions of galleries as places of 'no interest' have been portrayed by Mason and McCarthy $(2006,25)$ in their survey for the Auckland Art Gallery of Auckland, New Zealand. The findings from their stratified sample of 200 people aged between 16 and 26 found that young people would not choose to visit a gallery as a leisure attraction even though it was within close proximity. This was also portrayed within the context of this research. 
Although the young people were aware of the central location of the museum in the town (which was also in proximal distance to the school and did not have an entry fee) they never visited it. When the young people were asked to sketch an image and/or write the first words that come into their mind when they heard the word 'museum' the visual representation was usually that of a Greek/Roman temple isolated from real life in the city (Figure 1). On the basis of this feedback a meeting was held with the young people and the museum professionals to discuss the nature of the project. As part of this dialogue the need emerged for a collaborative enquiry that would shape the project and create a forum in which the young people and the museum would remake the practices in which they (or more pertinently do not) interact.

\section{Working as a 'community of researchers'}

Key to the PAR process is the establishment of 'a community of researchers' that share ownership of the research process (Cahill 2007a, 299). This involved the creation of a culture of systematic reflection within the group for this project. The group met every Friday afternoon after the end of the school day. For the first few months the meetings took place at the museum and rarely at the school setting. As the dynamics of the group evolved and the ownership of the project developed the group decided to meet at a cafe' close to the museum. The cafe' was seen as a friendly independent environment along the lines of the independent work that the group was doing beyond the territorial space of both the school and the museum:

Liam: We will sit at the cafe' $\ldots$ we agreed on doing it outside the school hours so we can carry on with our subjects. We are treated like adults. We have discussions. We are not schoolchildren that are told what to do. (extract from group reflection, 01/2006)

The framework for PAR was agreed through discussion from the beginning of the project. Engagement in this process involved 'a spiral of self-reflective cycles' during which the group planned a change, acted and observed the consequences of the action, reflected on the involved processes and accordingly re-planned the following steps. This was a messy process. Kemmis and McTaggart recognise that in the reality of PAR the stages of self-reflection overlap and 'initial plans become obsolete in the light of learning from experience' $(2005,563)$. Reflectionin-action was facilitated by the development of research skills, which is a common practice in PAR projects with young people (Torre et al. 2008). The group established as a priority to investigate the community's relationship with the local building and the facilities it offered. In order to establish a shared understanding of the research process the group began with 
discussions as to what constitutes research followed by informal training of research methods that built on skills already acquired by the students in work for their curriculum subjects. Such an approach recognises the balance between existing and new knowledge and is viewed by Kidd and Kral (2005) as an emancipatory process that shows respect for the legitimacy of the participants' knowledge:

Participants [...] are given access to expert knowledge regarding research and political action...[This] knowledge [...] can then combine to help people to understand and alter systems that were previously invisible. (189-190)

\section{Q4 What comes into your mind when you hear the word museum? (please sketch any image and/or write relevant words-expressions)}

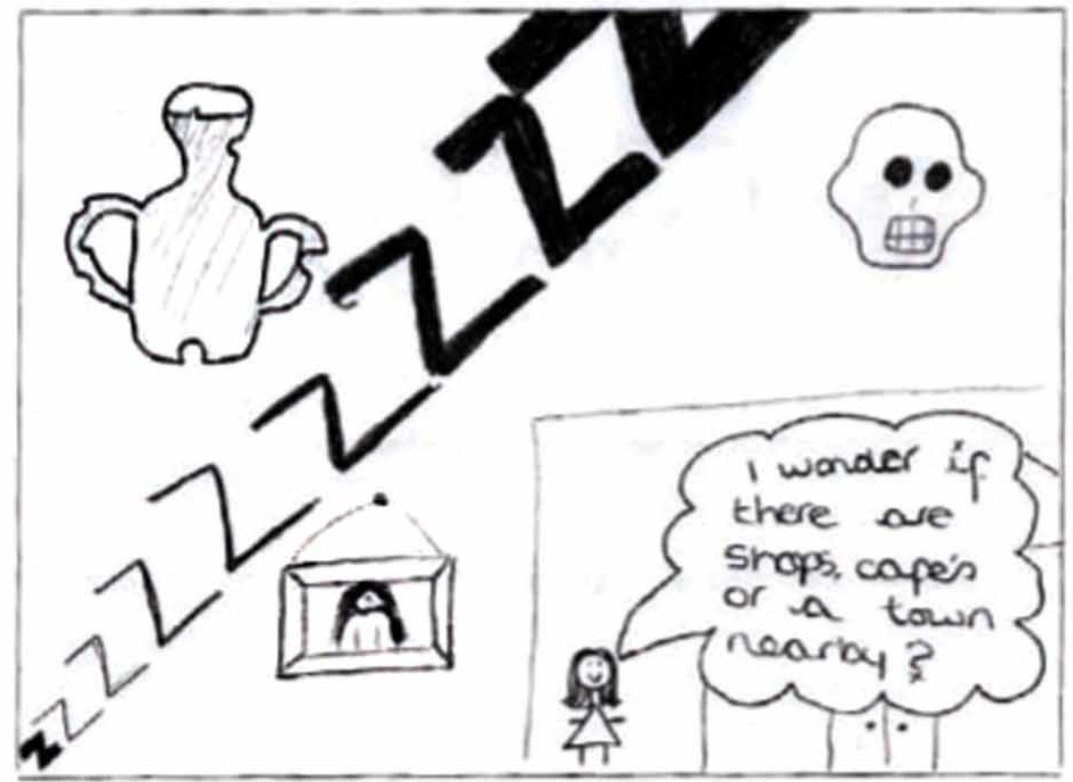

Q4 What comes into your mind when you hear the word museum? (please sketch any image and/or write relevant words-expressions)

I gind musems whan I thuite about them is when they have old pottery and coviss. They abose abo have nuins and old mbbish or baties

Figure 1. Examples of young people's responses to the open-ended questionnaire. 
The skills and knowledge of the artists who coordinated the project enhanced the process of reflection. Using the young people's expression of interests in advancing their art and technology skills the artists supported the students in film-making sessions that allowed the framing of the enquiry within an innovative context for the group. The young people videorecorded their interviews with the community, photographed the areas in the building that 'conveyed certain messages to the community' and created a DVD to document the process of enquiry. This process sparked enthusiasm for the project and created new avenues of enquiry which 'as in most PAR projects [. . .] informed the research process rather than demanded that it flow a certain way’ (McIntyre 2008, 50).

Whilst the young people gathered data from undertaking a survey and from interviews with people in the local high street and visitors to the museum, analyses of these were considered unhelpful. The reason cited for this by was the multiplicity of contrasting and contradicting views:

Andrew: It is so difficult to understand what people would like to see happening in the museum. We asked two people of the same age group more or less about what their thoughts were of the building and they said completely different things. (extract from group reflection, 05/2006)

The reflections that arose from the young people participation in the project as they disseminated and shared their work (to peers in other similar projects, at school events, the design of a website for shared access to the material collected for the museum's improvement and co-organisation of exhibitions for professional artists/ freelancers involved in the PAR) were considered to be much more valuable and informative. Thus, analysis of the understanding that the group generated through participation in the project emerged organically via reflection on actions taken for the exploration of research questions.

\section{Building trust}

From the outset there was awareness that power differentials were at play between the young people and the adults involved in the project (museum staff and freelance artists). The school identified the young people who would benefit from participating in a community project with 
the expectation that participation would enhance their educational attainment targets. On that basis the young people to whom the 'offer' to participate was made could be considered as underachievers who may benefit educationally from the museum experience. Therefore to create a genuinely inclusive space where ideas could be shared and explored it was important that these power differentials were openly addressed. As it has been highlighted by Pain, Kesby, and Kindon (2010), sharing power in the research process and building relationships of trust are crucial in the PAR process. During our meetings the roles were discussed openly in terms of responsibility for the research process and the steps involved. It was anticipated that 'mutual trust' would emerge as a 'logical consequence' (Freire [1970]1993, 70) from participation in critical dialogue and co-construction of understandings about the circumstances surrounding the (non) interaction between the young people and the museum.

Building trust was a gradual process that evolved from the flexible approach to the enquiry that respected and built on everyone's ideas and the allocation of resources under the young people's responsibility:

Kieran: At the beginning, to tell you the truth, I joined the group because the other guys said it would be good for me to join. They asked me to come and I said...yes. I did not know that it would be like that. The moment I really got into it was when N. and the group trusted the three of us to find sponsors and negotiate with managers. (extract from group reflection, 02/2007)

Artist: We're breaking down any barriers of us and them and saying 'actually I'm giving you this to use and I trust you to use it'. [ . . .] We can be flexible in helping them and where we've done that is actually listening to their ideas, what they think. [. . .] I think by being flexible and giving the responsibility to the students and working on their own ideas is where the trust happens. (extract from individual reflection, 02/2007)

Alex: It is nice to see your ideas developed, to be asked what you want to do. (extract from group reflection, 03/2006)

\section{Authentic and transformative participation}

One of the criteria for success within PAR is whether the participants have an authentic sense of how their 'understandings of their practices and the situations in which they practice' have 
developed (Kemmis and McTaggart 2005, 563). Given that 'practice' can take various forms depending on the focus and 'context-specificity' of PAR (McIntyre 2008, 2), 'practice' within the context of this project was viewed in the widest sense as the young peoples' engagement in the museum's regeneration. Genuine participation was a prerequisite for the recursive circles of reflection to develop. As illustrated in a diverse range of PAR projects (Cahill 2007b; Fine and Torre 2004; Pratt et al. 2010; Savin-Baden and Wimpenny 2007) through this reflective process a sense of agency develops that strengthens the participants' confidence and sense of identity. Self- and critical awareness is promoted that does not only lead to individual but also to collective changes within the social reality. These transformations, may be subtle or more overt (Pain, Kesby, and Kindon 2010), are an integral and vital component of the research process if PAR is to remain true to its emancipatory potential.

\section{On PAR and individual transformation}

The young people's reflection on their own involvement in the project reveals that participation was a transformative experience per se. The ownership and responsi- bility of the activities strengthened the young people's belief in their own self-worth, skills and determination to pursue their interests within and beyond the school context. In reflections on the quality of the lived experiences, at the completion of the two years of the project, the comments were focused on the new perceptions and ideas about their own capabilities:

Becky: My expectations changed. When we started I thought, this is really good . . . it will help me with my art and make me think what I want to do. I wanted to look at parts of art but now I am going broader looking at galleries. (extract from individual interview, 04/2008)

Daniel: [. . .] Probably my social skills have gone up as well as my confidence and my speech and all that by talking to people, different types of people [...] there are more things I would like to be involved in. I'd like to get somewhere and to do very well. Before I would hesitate ... Now I would just get up and do it. I am really proud I have done this project. [...] In general, everyone's confidence has gone up. (extract from individual interview, 04/2008)

Kieran: I am proud of the quality of the work we did. [...] Where I used to see scribbles, now, I see art. (extract from individual interview, 04/2008) 
The young people's comments suggest that genuine participation in PAR was rooted in the ownership of the experience. The engagement in a 'dialogical authoring process' (Romero et al. 2008, 136) supported self-determination and rearticulation of the mediating structures between museums and its actual and potential visitors. The local museum is not anymore 'a building that happened to be there' remote from the city and the community but is deemed to be a product of decisions taken by curators and other staff. Museums are reconceptualised as democratic institutions that belong to all. Through the enquiry into the facilities and the perceptions of the building the group unexpectedly found that the museum can be significant for others. By committing to its regeneration for all, it is as if the group of young people reclaimed their own space in the community:

Sam: I have a different point of view of where I live and who lives around me. [ . .] Some people really depend on this building while for others it does not matter it will close for a while. I spoke to people who said 'I really need the museum'. First you think, oh, it is just a gallery space [. . .] But attracting people within the museum is a different thing. It is a community within the community. It changed the way I view the city now. (extract from individual reflection, 04/2008)

The group's perceptions on the role of museums as community institutions and the challenges that museum professionals have to face were deepened when the young people, in collaboration with three professional artists who were involved in the project to support the group's needs, co-curated an exhibition in a gallery in London. Through this experience a first-hand understanding evolved of processes of exhibition development and parameters that shape museums and their practices (i.e. limitations and potential of space, communication modes within the museum space, style and tone of communication in label writing). The co-creation of an exhibition offered a practical arena for the group to put into practice their critical views of other museum spaces they had formerly reviewed. It was vital in this process that there were group discussions to explore individual views and ideas so that each participant felt valued and not compromised in the final collective decision. As in other PAR projects with community groups and young people (Tuck et al. 2008) reaching a collective agreement is not always a straightforward process. The following extract is taken from a group discussion:

Martin: We became curators [...] it is a fresh pair eyes that look at the picture, different opinions. 
Peter: The project gave me some sense of what the people who work in a museum have to put up with and how they are going to put things up on an exhibition. I didn't think it was that hard at first but really it is hard. We had to think as a group about other people's opinions. [...] What is the best place to show it? If it is bright...if it is a bit of metal. [. . .] If somebody agrees about a piece of artwork and I do not, people should hear it...and so we all got a part in it.

(extract from group reflection, 06/2008)

Not only have the young people begun to see themselves as reflectors and active participants in their reality but also they have developed a sense of how participation in the PAR process is and can be viewed by others. They are interested in invoking a pedagogy of participation that includes everyone's interests and allows experimentation and learning from the collective experience. The following is an extract from a discussion on how PAR might work for other groups of young people:

Peter: They have to learn from their experience. They have to learn from their own mistakes as we did from our own.

Ben: . . s similar projects will work if groups make sure that thought and action are evenly spread. Try to break up things and not have long period only of thought. What keeps you interested in the project is to think about what you are going to do and then do it, do presentations, exhibitions, listen to other people's views and work ...

Liam: I think we did not mind thinking of stuff while other people just wanted to create stuff and got bored with the discussions. In the future similar projects need to include all and do things that everybody is interested in.

Becky: People in the school sometimes say 'are you still doing that ...' they think it is boring because it is a museum project. 
Becky: yes ... but I do not blame them. Museums, like this one, are boring [referring to the museum's physical space that remained unaltered]. They can make young people feel unwelcomed ... But we are doing so much. They would not believe it.

(extract from group reflection, 07/2008)

\section{Transformative participation in the museum}

Although the young people's reflections suggest that participation was authentic and transformational on an individual level, questions need to be posed about the extent to which the PAR process was transformational for the institution and its practices. A follow-up interview with the museum's curator at the final stages of the project demonstrated some changes in the re-structuring of the museum staff (e.g. employ- ment of an outreach officer) and a willingness to further involve community groups to museum projects:

Curator: We're still struggling to understand how projects can be entirely communityled. Part of the ongoing work with the PAR project is I think helping to raise our awareness and our capacity for change and development. We gained experience about the amount of support that community groups such as young people need before they can make an informed view back to us. (interview extract, 05/2008)

The young people's concerns about transformation in the actual museum space were clearly articulated even within the initial stages of their engagement in PAR. Questions arose about the museum's communication with its visitors via facts- orientated label writing and didactic displays. The museum space was criticised for its lighting, its lack of interactivity and choice for exhibitions that are not appealing to young people. The following extract is taken from a discussion based on visual material that the group collected from the building:

Collin: The advertising posters at the front of the building should be moving to catch people's eyes.

Allan: People walk passed it and they do not even notice that there are exhibitions here.

Liam: Perhaps if the reception was modernised...The posters need to be more colourful and lighter to attract young people, to make it look warmer. 
Becky: Even when people are coming in, they cannot find out what exhibition is on unless they go upstairs.

Martin: Younger people want more technological things. We do not like reading texts when we can get more things at the internet.... They need to have music, CDs...to allow you to download ....

Liam: There are different people that like different things, not everyone likes cows, you can go to the field and see one....

Kieran: The information about the pictures is really small.

Liam: Yes, the writing is too small and too formal for people to read...too much information.

When you go pass them and you don't read them ....

Alex: I would like to see in the museum exhibitions about stuff that young people want to see, like paranormal stuff, sports, music, pictures and videos from sports, some people coming in to talk and give lectures and stuff.

Ben: More interactivity

(extract from group reflection, 11/2007)

At various stages of the project the young people expressed the desire to display the outcomes of their enquiry within the museum space, to communicate directly with the curatorial staff, to contribute to the venue's practices and to be actively engaged in decision-making in regard to the building's regeneration. Nonetheless, during the project there were no clear indications that their opinions were valued and acted upon. When the group expressed the desire to prepare a display for potential visitors of their age group, they obtained access only to a collection of domestic vacuum cleaners that according to the curators were robust and not in danger to be damaged. As a result, within a two-week period the group's membership to the project dropped from 15 to 8 students.

A consultation session took place with the County Council in order to find out the young people's views about the current building and its facilities. The practice of 'consultation 
groups' in museums is a prerequisite for funding initiatives (Arts Council England 2011; Heritage Lottery Fund 2010) since they are perceived to encourage communication with the community and participation in the institutions' decision-making. However, there is not much evidence for the merits that such forms of communication have for all parties involved. Decisions in cultural policy are taken by experts behind closed doors, and the communities are consulted once the plans have been put in place (Young 2002). Concerns have also been expressed about the use of youth forums and consultation as means that promote young people's participation in community decision-making (Matthews 2001; Patridge 2005; Woolfson et al. 2006). This is also acknowledged as an issue by the museum's curator when reflecting on the extent to which consultation with the young people affected the plans for the museum's regeneration:

Curator: I'm not sure how much the consultation did more than reinforce those thoughts that were already within the team awareness at some level. I think what the project and the consultation have done is simply to legitimise our thoughts to change the dynamics of that building in its relationship to local communities. (interview extract, 05/2008)

Within the context of this study, the young people stated that ongoing consultation and reflection with the museum staff would have contributed to having their views listened to and also acted upon. At various stages of this project it became evident that the group's decisions for action within the museum space were mediated by the museum professionals' judgements about what was regarded as feasible and realistic. The curators' perception about young people was a catalyst factor influencing the activities in which the young people could be engaged. Outcomes of the group's work could not be put on display because they were not considered to be of a professional standard and any activities that would result in more permanent changes within the museum space were discouraged. The following excerpts are taken from the group's reflections at the completion of the project:

Daniel: People in the group wanted to create and to see immediately the changes within the museum. We could do what we can do as group, we discussed our ideas but not with the museum and library staff because they were not really there when we did the showings. We spoke to some staff but that was it all. Oh . . yes, in the first year we met more people and then less. There were some that thought...'mmm...young people they should not really be doing this', but we are doing it anyway. We got older and we 
know what is professional and what is not. We are improving ... . (extract from group reflection, 06/2008)

\section{Concluding remarks}

Although this is a small-scale study, the young people's reflections suggest that PAR offers a critical framework for community engagement in cultural heritage. It can be a powerful process that challenges the preconceptions, the boundaries and the practices that have become the norm in the development of inclusive museum practices. If museums are to create a participatory culture in which young people are co-creators of museum experiences, they have to trust the participants' abilities, ${ }^{4}$ to engage in meaningful dialogue and encourage genuine participation and transformative praxis for all stakeholders involved in such projects. However, effecting change with PAR might be difficult especially when institutions have to act on recommendations that are at odds with prevailing perceptions and practices (Cameron 2010). If institutional transformation remains to be pursued, we risk involving young people in projects that only act as vehicles for self-development.

Inclusion is not an abstract quality isolated from the museums' ideological performance as socio-cultural institutions. Museums and galleries are called to conceptualise their role as responsible social institutions that do not merely succumb to pressures from changes in governmental policy and agendas (Coffee 2008; Tlili, Gerwirtz, and Cribb 2007; Sandell 2002). The real challenge is young people's inclusion to become an integral part of the museum's identity that permeates all aspects of museum work and moves away from transmission views of educational provision for a homogeneous group. Perhaps when it comes to young people's participation in these processes, the call for museums to become increasingly reflexive and critical becomes an ethical imperative beyond the boundaries of policy making.

\section{Notes}

1. The museum's identity is withheld and all participants' names are changed to safeguard anonymity.

2. To name a few of these programmes and initiatives: 'Renaissance in the Regions', 'Creative Partnerships', the 'Strategic Commissioning Programme for Museum and Gallery Education' and the series of action research initiatives led by 'Engage' in the area of visual art and gallery education.

3. At the Whitechapel Art Gallery young people participated in the production of videos that were shown in the galleries (Herne and McLaren 2001). Tate Galleries in the UK searching for new channels to communicate with young people extended their 
marketing approaches to young people and showcased music based on the artworks to give youth an access point into collection displays (Briggs 2007). They developed a series of youth programmes among which the language-based workshops called 'we are all experts' to enable young people to voice and have their views about art heard (Sayers 2011).

4. Trust in participants' abilities is also highlighted by Simon (2010) as a prerequisite for the development of co-creative projects in museums.

\section{Notes on contributor}

Vasiliki Tzibazi is a senior lecturer in the Postgraduate Studies in Education at the University of Winchester. She holds a PhD in museum studies from the University of Leicester. She has published articles within the area of museum theatre and developed research projects with BA student teachers in the field of museum education. This paper focuses on her work as project coordinator and evaluator in museum programmes for children and young people.

\section{References}

Arts Council England. 2011. Accreditation Scheme for Museum and Galleries in the United Kingdom- Guidance. http://www.artscouncil.org.uk/media/uploads/pdf/Accreditationguidance_section_three_Dec2011.pdf

Barlett, A., and L. Kelly. 2009. Young People and Museums. Australian Museum Audience Research Centre. http://australianmuseum.net.au/Young-People-and-Museums/

Belfiore, E., and O. Bennett. 2010. "Beyond the Toolkit Approach: Arts Impact Evaluation Research and the Realities of Cultural Policy-Making." Journal for Cultural Research 14 (2): 121-142. doi:10.1080/14797580903481280.

Bellamy, K., and C. Oppenheim, eds. 2009. Learning to Live: Museums, Young People and Education. London: Institute for Public Policy Research and National Museums Director's Conference.

Briggs, S. 2007. “Fresh Eyes: Attracting and Sustaining Young Visitors to Tate." Museum Management and Curatorship 22 (1): 5-9. doi:10.1080/09647770701264390.

BOP. 2006. MLA North West, MLA and Renaissance North West. Review of museum, Library and Archive Activity with Children and Young People. Final Report. http://www.mla.gov. uk/about/region/North_West//media/Files/pdf/2006/mla_nw_children_young_people

Cahill, C. 2007a. " Doing Research with Young People: Participatory Research and the Rituals of Collective Work." Children's Geographies 5 (3): 297-312. doi:10.1080/1473328070144 5895.

Cahill, C. 2007b. "The Personal is Political: Developing New Subjectivities Through Participatory Action Research." Gender, Place and Culture 14 (3): 267-292. doi:10.1080/ 09663690701324904. 
Cameron, J. 2010. "Linking Participatory Research to Action." In Participatory Action Research Approaches and Methods, edited by S. Kindon, R. Pain, and M. Kesby, 206-215. London: Routledge.

Coffee, K. 2008. ' Cultural inclusion, exclusion and the formative roles of museums.' Museum Management and Curatorship 23 (3): 261-279. doi:10.1080/09647770802234078.

Cooke, B., and U. Kothari, eds. 2001. Participation; The New Tyranny. London: Zed Books.

DCMS. 2000. Centres for Social Change: Museums, Galleries and Archives for All: Policy Guidance on Social Inclusion for DCMS Funded and Local Authority Museums, Galleries and Archives in England. London: Department of Culture, Media and Sport.

DCMS. 2005a. Archive 183/05. http://www.culture.gov.uk/reference_library/media_releases/ 2942.aspx

DCMS. 2005b. National Youth Agency Response to Consultation on Understanding the Future: Museums and 21st Century Life. London: DCMS.

DCMS. 2007. Culture on Demand; Ways to Engage A Broader Audience. London: DCMS.

DCMS. 2008. Supporting Excellence in the Arts. From Measurement to Judgment. London: DCMS. http://www.audiencesnortheast.org.uk/tpl/uploads/1McMaster_Review_1.pdf

DfES. 2005. Youth Matters. Presented to Parliament by the Secretary of State for Education and Skills by Command of Her Majesty. HMSO.

DFES. 2006a. Learning Outside the Classroom Manifesto. Nottingham: DFES.

DFES. 2006b. Youth Matters: Next Steps. Something to Do, Somewhere to Go, Someone to Talk to. Nottingham:DfES.

DFES. 2007. Aiming High for Young People: A Ten Year Strategy for Positive Activities. London: HMSO.

Discovery. 2011. Renaissance East of England: Stepping Stones Evaluation Final Report. Norfolk: Discovery East. http://www.mla.gov.uk/what/programmes/renaissance/regions/ east_of_england/news//media/East_of_England/Files/2011/Rennaisance $\% 20$ East $\% 20 \mathrm{of} \%$ 20England\%20-\%20Stepping\%20Stones\%20Final\%20Report\%20v1.ashx

Elden, M., and M. Levin. 1991. "Cogenerative Learning, Bringing Participation in Action Research.' In Participatory Action Research, edited by F. W. Whyte, 127-142. London: Sage. 
Fals Borda, O. 2006. "Participatory (Action) Research in Social Theory: Origins and Challenges.' ' In Handbook of Action Research. The Concise Paperback Edition, edited by P. Reason and H. Bradbury, 27-37. London: Sage.

Fine, M. 2008. “An Epilogue, of Sorts.' In Revolutionizing Education, Youth Participatory Action Research in Motion, edited by J. Cammarota and M. Fine, 213-234. New York: Routledge.

Fine, M., and M. E. Torre. 2004. ' Re-membering Exclusions: Participatory Action Research in Public Institutions.' Qualitative Research in Psychology 1: 15-37.

Freire, P. [1970]1993. Pedagogy of the Oppressed. London: Perguin Books.

Freire, P. 1998. Pedagogy of Freedom. Ethics, Democrary, and Civic Courage. Lanham: Rowman and Littlefield.

Gaveta, J., and A. Cornwall. 2006. ' Power and Knowledge.' In Handbook of Action Research. The Concise Paperback Edition, edited by P. Reason and H. Bradbury, 71-82. London: Sage.

Greene, M. 2001. Blue Guitar. The Lincoln centre Institute Lecturers on Aesthetic Education. New York: Teachers College, Columbia University.

Harland, J., and K. Kinder, eds. 1999. Crossing the Line; Extending Young People's Access to Cultural Venues. London: Calouste Gulbenkian Foundation

Harris, K., and M. Dudley. 2011. 'I didn't know I could' Museums and young people looked after. MLA Renaissance East of England. http:/www.mla.gov.uk/what/programmes/renaissance/regions/east_of_england/news//media/East_of_England/Files/2011/MACLA_report_ Final.ashx

Hawthorne, E., and K. Pontin. 2001. 'Museum Fever' and 'Represent': Lessons for Working with Young People in Museums. Birmingham: WMRMC.

Heritage Lottery Fund (HLF). 2007. Young People's Heritage Projects: A Model of Practice. London: Heritage Lottery Fund, Leicester: The National Youth Agency.

Heritage Lottery Fund (HLF). 2010. Thinking about . . Community Participation. http://www. hlf.org.uk/HowToApply/furtherresources/Documents/Thinking_about_community_partici pation.pdf

Herne, S., and J. McLaren. 2001. "A Toe in the Water: Introducing Exhibitions on Video with Young People at the Whitechapel Art Gallery." JADE 20 (3): 284-295. 
Hooper-Greenhill, E. 2000. Museums and the Interpretation of Visual Culture. London: Routledge.

Hooper-Greenhill, E. 2007. Museums and Education. London: Routledge.

Ings, R. 2001. Funky on Your Flyer. London: Arts Council England.

Kemmis, S., and R. McTaggart. 2005. "Participatory Action Research. Communicative Action and the Public Sphere.' In The Sage Handbook of Qualitative Research, edited by N. Denzin and Y. Lincoln, 559-604. Thousand Oaks: Sage.

Kidd, S. A., and M. J. Kral. 2005. "Practicing Participatory Action Research.' Journal of Counseling Psychology 52 (2): 187-195. doi:10.1037/0022-0167.52.2.187.

Kindon, S., R. Pain, and M. Kesby. 2010. Participatory Action Research Approaches and Methods: Connecting People, Participation and Place. Abingdon and New York: Routledge.

Krimerman, L. 2001. "Participatory Action Research: Should Social Inquiry Be Conducted Democratically?" Philosophy of the Social Sciences 31 (1): 60-82. doi:10.1177/004839310103 100104

Leahy, H. R. 2007. “New Labour, Old Masters.'” Cultural Studies 21 (4-5): 695-717. doi:10. 1080/09502380701279036.

Mason, D. M., and C. McCarthy. 2006. “' "The feeling of exclusion': Young Peoples' Perceptions of Art Galleries.' Museum Management and Curatorship 21: 20-31.

Matthews, H. 2001. "'Participatory Structures and the Youth of Today: Engaging Those Who Are Hardest to Reach.” Ethics, Place and Environment 4 (2): 153-159.

McIntyre, A. 2000. Inner-City Kids: Adolescents Confront Life and Violence in an Urban Community. New York: New York University Press.

McIntyre, A. 2008. Participatory Action Research. Qualitative Research Methods Series 52. A Sage University Paper. London: Sage.

MLA. 2008. Inspiring Learning for All. http://www.inspiringlearningforall.gov.uk/

Newman, A., and F. McLean. 2004. "Presumption, Policy and Practice. The Use of Museums and Galleries as Agents of Social Inclusion in Great Britain.' International Journal of Cultural Policy 10 (2): 167-181. doi:10.1080/1028663042000255790. 
Pain, R., and P. Francis. 2003. "Reflections on Participatory Research.” Area 35 (1): 46-54. doi:10.1111/1475-4762.00109.

Pain, R., M. Kesby, and S. Kindon. 2010. "Conclusion: The Space(s) and Scale(s) of Participatory Action Research: Constructing Empowering Geographies?' In Participatory Action Research Approaches and Methods, edited by S. Kindon, R. Pain, and M. Kesby, 225230. London: Routledge.

Patridge, A. 2005. "Children and Young People's Inclusion in Public Decision-making." Support for Learning 20 (4): 181-189. doi:10.1111/j.0268-2141.2005.00386.x.

Pontin, K. 2009. “'Why Young People? Attracting A New Audience to Our Museums.' In Learning to Live: Museums, Young People and Education, edited by K. Bellamy and C. Oppenheim, 103-112. London: Institute for Public Policy Research and National Museums Director's Conference.

Potter, S. 2006. "Children and Young People in Museum Evaluation." In The Responsive Museum: Working with Audiences in the Twenty- First Century, edited by C. Lang, J. Reeve, and V. Woollard, 129-131. Aldershot: Ashgate.

Pratt, G. in collaboration with the Philippine Women Centre of BC and Ugnayanng Kabattaang Pilipino sa Canada/Filipino-Canadian Youth Alliance. 2010. "Working with Migrant Communities.' In Participatory Action Research Approaches and Methods, edited by S. Kindon, R. Pain and M. Kesby, 95-103. London: Routledge.

Reason, P., and H. Bradbury, eds., 2006. Handbook of Action Research. The Concise Paperback Edition. London: Sage.

Rider, S., and S. Illingworth. 1997. Museums and Young People. London: The Museums Association.

Romero, A., J. Cammarota, K. Dominguez, L. Valdez, G. Ramirez, and L. Hernandez. 2008. “" The Opportunity If Not the Right to See': The Social Justice Education Project' In Revolutionizing Education, Youth Participatory Action Research in Motion, edited by J. Cammarota and M. Fine, 131-151. New York: Routledge Taylor and Francis Group.

Rosso, N. 2010. Youth-led Practice in Galleries, Museums and Archives. London: Engage. Sandell, R., ed. 2002. Museums, Society and Inequality. London: Routledge.

Savin-Baden, M., and K. Wimpenny. 2007. "Exploring and Implementing Participatory Action Research.' Journal of Geography in Higher Education 31 (2): 331-343. doi:10.1080/ 03098260601065136.

Sayers, E. 2011. "Investigating the Impact of Contrasting Paradigms of Knowledge on the Emancipatory Aims of Gallery Programmes for Young People.' International Journal of Art and Design Education 30 (3): 409-422. doi:10.1111/j.1476-8070.2011.01720.x. 
Scott, C. 2002. “Measuring Social Value.” In Museums, Society and Inequality, edited by R. Sandell, 203-212. London: Routledge.

SEU. 2004. Tackling Social Exclusion: Taking Stock and Looking to the Future. http://www. socialexclusionunit.gov.uk/downloaddoc.asp?id-13

Selwood, S. Associates. 2010. Making A Difference: The Cultural Impact of Museums. Executive Summary: An Essay for NMDC. http://www.nationalmuseums.org.uk/media/ documents/publications/cultural_impact_exec_summary.pdf.

Shared Intelligence. 2007. MLA Improvement Tools Study.

http://research.mla.gov.uk/evidence/ documents/

Silverman, H. L. 2010. The Social Work of Museums. Abingdon: Routledge.

Simon, N. 2010. The Participatory Museum. California: Museum20.

Tlili, A. 2008. "'Behind the Policy Mantra of the Inclusive Museum: Receptions of Social Exclusion and Inclusion in Museums and Science Centres.' Cultural Sociology 2 (1): 123147. doi:10.1177/1749975507086277.

Tlili, A., S. Gerwirtz, and A. Cribb. 2007. “New Labour's Socially Responsible Museum. Roles, Functions and Greater Expectations.'” Policy Studies 28 (3): 269-289. doi:10.1080/ 01442870701437634.

Torre, M. E., M. Fine, N. Alexander, A. M. Billups, Y. Blanding, E. E. Genao, E. Marboe, T. Salah, and K. Urdang. 2008. 'Participatory Action Research in the Contact Zone.' In Revolutionizing Education, Youth Participatory Action Research in Motion, edited by J. Cammarota and M. Fine, 23-44. New York: Routledge Taylor and Francis Group.

Tuck, E., J. Allen, M. Bacha, A. Morales, S. Quinter, J. Thompson, and M. Tuck. 2008. "PAR Praxes for Now and Future Change.' In Revolutionizing Education, Youth Participatory Action Research in Motion, edited by J. Cammarota and M. Fine, 49 83. New York: Routledge Taylor and Francis Group.

Wavell, C., G. Baxter, I. Johnson, and D. Williams. 2002. Impact Evaluation of Museums, Archives and Libraries: Available Evidence Project. Aberdeen: The Robert Gordon University, report for Re:source. http://www4.rgu.ac.uk/files/imreport.pdf

Woolfson, R. C., M. Harker, D. Lowe, M. Shields, M. Banks, L. Campbell, and E. Ferguson. 2006. "Consulting About Consulting: Young People's Views of Consultation.' Educational Psychology in Practice 22 (4): 337-353. doi:10.1080/02667360600999468. 
Xanthoudaki, M. 1998. "Educational Provision for Young People as Independent Visitors to Art Museums and Galleries: Issues of Learning and Training.' Museum Management and Curatorship 17 (2): 159-117. doi:10.1080/09647779800401702.

Young, L. 2002. ' Rethinking Heritage: Cultural Policy and Inclusion.'” In Museums, Society, Inequality, edited by R. Sandell, 203-212. London: Routledge. 